\title{
Evaluation of functional state of muscular system in children with diabetes mellitus
}

\author{
0. Ye. Pashkova ${ }^{\circledR} *$ A,E,F, N. I. Chudova ${ }^{B-D}$
}

Zaporizhzhia State Medical University, Ukraine

A - research concept and design; B - collection and/or assembly of data; C - data analysis and interpretation; D - writing the article; $\mathrm{E}$ - critical revision of the article; $\mathrm{F}$ - final approval of the article

Key words:

type 1 diabetes,

children, muscular

strength, diabetic

myopathy.

Pathologia

2020; 17 (2), 164-169

*E-mail:

elenapashkova0901@

gmail.com
Aim. To evaluate the functional condition of skeletal muscles in children with type 1 diabetes (T1D), according to the duration of disease based on studying static and dynamic physical endurance.

Materials and methods. 76 children with T1D from 11 to 17 years old were examined. The first group included 20 kids with the duration of diabetes less than 1 year. The second group -27 patients with T1D from 1 to 5 years. The third group -29 kids with T1D over 5 years. The group of control included 16 conventionally healthy children. Static muscular endurance with evaluation of total static muscular endurance (TSME) and dynamic muscular endurance with evaluation of wrist strength index (WSI) were evaluated. The index of muscle quality (IMQ) was evaluated too.

Results. The greater duration of T1D was accompanied by the redistribution of percentage ratio of body components. The TSME was decreasing alomg with increase of T1D duration. Reverse correlation between glycated hemoglobin and TSME $(r=-0.50 ; P<0.05)$ was shown. The dynamic endurance revealed the progressing decrease of WSI before and after the physical exertion in children with T1D in comparison with the control group. The revealed peculiarities of functional condition of muscles were connected with TSME $(r=+0.43, P<0.05)$ and IMQ $(r=+0.52, P<0.05)$.

Conclusions. Functional condition of skeletal muscles in children with T1D is characterized by decrease of static and dynamic muscular endurance. The first signs of changes are observed over the first year of disease and progress as the duration of a disease increases and leads to decrease of mucle mass and diabetic myopathy developing. The major factor contributing the worsening of functional condition of muscles is insufficient glycemic control.
Ключові слова: цукровий діабет 1 типу, Аіти, витривалість м'язів, діабетична міопатія.

Патомогія. 2020. T. 17, № 2(49). C. $164-169$

\section{Оцінювання функціонального стану м'язової системи в дітей, які хворі на цукровий діабет}

\section{О. Є. Пашкова, Н. І. Чудова}

Мета роботи - оцінити функціональний стан скелетної мускулатури в дітей із цукровим діабетом 1 типу (ЦД1) залежно від тривалості захворювання на основі вивчення статичної та динамічної фізичної витривалості.

Матеріали та методи. Під спостереженням перебували 76 дітей віком від 11 до 17 років, які хворі на ЦД1. У 1 групу ввійшли 20 дітей із тривалістю ЦД1 до 1 року, у 2 групу - 27 дітей із перебігом захворювання від 1 до 5 років, у 3 групу - 29 дітей із тривалістю ЦД1 понад 5 років. Групу контролю становили 16 умовно здорових дітей. Для оцінювання функціонального стану м'язової системи визначали статичну й динамічну витривалості скелетних м'язів з обчисленням сумарної статичної витривалості (CСB) та індексу кистьової сили (ІКС). Також визначали показник якості м'язів (ПЯМ).

Результати. Збільшення «стажу» ЦД1 супроводжувалося перерозподілом компонентного складу тіла. Зі збільшенням тривалості ЦД1 погіршувався показник ССВ. Виявили зворотний кореляційний зв'язок між глікованим гемоглобіном і ССВ $(r=-0,50 ; p<0,05)$. Під час дослідження динамічної витривалості виявили зниження IКС до та після навантаження в дітей із ЦД1 порівняно з групою контролю, що прогресувало в динаміці захворювання. Виявлені особливості фуннціонального стану м'язів пов'язані з показником CСB $(r=+0,43, p<0,05)$, а також із ПяМ $(r=+0,52, p<0,05)$.

Висновки. Функціональний стан скелетної мускулатури в дітей із ЦД1 характеризувався зниженням статичної та динамічної м'язової витривалості. Перші ознаки змін спостерігали вже на першому році захворювання, вони прогресують зі збільшенням тривалості ЦД1 і призводять до зниження м'язової маси, розвитку діабетичної міопатії. Основний фактор ризику, що зумовлює погіршення функціонального стану скелетних м'язів, - недостатній глікемічний контроль.

\section{Оценка функционального состояния мышечной системы у детей, больных сахарным диабетом}

1 типа, Аети выносливость мышц, миопатия.

Патология. 2020.

T. 17, № 2(49)

C. $164-169$

\section{Е. Е. Пашкова, Н. И. Чудова}

Цель работы - оценить функциональное состояние скелетной мускулатуры у детей с сахарным диабетом 1 типа (СД1) в зависимости от длительности заболевания на основании изучения статической и динамической физической выносливости.

Материалы и методы. Под наблюдением находились 76 детей в возрасте от 11 до 17 лет, больных СД1. В 1 группу вошли 20 детей с продолжительностью СД1 до 1 года, 2 группу составили 27 детей с длительностью заболевания от 
1 до 5 лет, 3 группа состояла из 29 детей с длительностью СД1 более 5 лет. Группу контроля составили 16 условно здоровых детей. Для оценки функционального состояния мышечной системы определяли статическую и динамическую выносливость скелетных мышц с вычислением суммарной статической выносливости (ССВ) и индекса кистевой силы (ИКС). Также оценивали показатель качества мышц (ПКМ).

Результаты. Установлено, что увеличение «стажа» СД1 сопровождалось перераспределением компонентного состава тела. С увеличением продолжительности СД1 ухудшался показатель ССВ. Установлена обратная корреляционная связь между гликированным гемоглобином и ССВ $(r=-0,50 ; p<0,05)$. При исследовании динамической выносливости отмечено снижение ИКС до и после нагрузки у детей с СД1 в сравнении с группой контроля, которое прогрессировало в динамике заболевания. Особенности функционального состояния мышц связаны с показателем CСВ $(r=+0,43$, $p<0,05)$, а также с ПКМ $(r=+0,52, p<0,05)$.

Выводы. Функциональное состояние скелетной мускулатуры у детей с СД1 характеризуется снижением статической и динамической мышечной выносливости. Первые признаки изменений наблюдали уже на первом году заболевания, они прогрессируют с увеличением длительности СД1, приводят к снижению мышечной массы и развитию диабетической миопатии. Основной фактор риска, который способствует ухудшению функционального состояния скелетных мышц, - недостаточный гликемический контроль.

It is well known that type 1 diabetes (T1D) is considered to be one of the specific risk factors of sarcopenia developing in adults. At the same time, there is lack of publications regarded to disturbances of musculoskeletal system in children with T1D. Although it is a junior age that is being a critical period in formation of skeletal system. According to the latest researches it is notices that there is a reduction in level of physical training in children with T1D compared to healthy kids even in terms of the equal level of physical activity [1]. That may point to the diabetic myopathy progress - the condition characterized by both muscle mass and function reduction [2].

Considering the importance of skeletal muscles in metabolism of lipids and glucose from the blood, the progress of diabetic myopathy may lead to both insulin resistance evolution and ability to lessen dysglycemic/dyslipidemic exertion [3]. The results of the latest researches have shown the increase of KLF15 protein in skeletal muscles of animals with inducted T1D in terms of hyperglycemia due to lowering of ubiquitin-ligase E3WWP1 regulation and the further diminishing of KLF15 destruction, which depends on ubiquitin and thus, contributes to muscle atrophy [4].

The data of the effect of physical activity on glycemic control in T1D are controversial. But according to the data obtained by Chimen et al. (2012) physical exertion didn't cause any positive effect on the level of glycated hemoglobin (HbAc1) in children with T1D. The other resources revealed the data about the credible reduction of level of $\mathrm{HbAc1}$ in teenagers with T1D going through the dosed aerobic physical exertion [5].

The anxiety of hypoglycemia progressing after the physical training is considered to be one of the negative factors that restrict the physical activity in kids and teenagers with T1D. The other factor is lack of glycemic control. So that, tests applied for the early diagnosing of disturbances in skeletal muscles system, that always accompany the progress of diabetic myopathy, can be very useful.

\section{Aim}

The aim was to evaluate the functional condition of skeletal muscles in children with T1D, according to the duration of disease based on studying static and dynamic physical stamina.

\section{Material and methods}

76 children with T1D from 11 to 17 years old were monitored. According to the duration of the disease all children were divided into three groups. The first group included 20 kids with the duration of diabetes less than 1 year. The second group includes 27 patients with the duration of diabetes from 1 to 5 years. The third group was formed of 29 kids with the duration of diabetes over 5 years. The group of control includes 16 conventionally healthy children. All groups were representative according to the age, gender and body mass index (Table 1).

All the kids went through the measuring of body weight and length with the further evaluation of body mass index (BMI). The muscular mass in kids below 14 years old was estimated according to A.M. Peters' formula [6]. The P. Boer's formula was applied for kids above 15 years old and counted the gender [7]. In order to evaluate the condition of muscular system, the skeletal muscle index (SMI) was assessed according to the formula [8]:

$$
\mathrm{SMI}=(\text { skeletal } \text { muscle mass } / \text { body mass }) \times 100
$$

In children under 15 years old the body fat percentage (BFP) was evaluated applying the following formula [9].

$$
\mathrm{BFP}=(1.51 \times \mathrm{BMI})-(0.70 \times \text { age })-(3.6 \times \mathrm{S})+1.4
$$

Where: $S$ - 1 for boys and 0 for girls; BMI - Body mass index; age - age in years.

In children over 15 years old the body fat percentage (BFP) was evaluated applying the following formula [9].

$$
\mathrm{BFP}=(1.20 \times \mathrm{BMI})+(0.23 \times \text { age })-(10.8 \times \mathrm{S})-5.4
$$

Where: $\mathrm{S}-1$ for boys and 0 for girls; BMI - Body mass index; age - age in years.

Body fat mass (BFM) was evaluated applying the following formula:

$$
\mathrm{BFM}=(\mathrm{BFP} / 100) \times \text { weight, }
$$

Where: BFP - body fat percentage; weight - weight in $\mathrm{kg}$.

The ratio between the fatty and muscle mass was evaluated in the following way: fatty mass in $\mathrm{kg}$ divided by muscle mass in $\mathrm{kg}$ and expressed in conventional units $(\mathrm{CU})$. 
Table 1. Distribution of children by age and gender, observation groups

\begin{tabular}{|c|c|c|c|c|}
\hline Criteria, units & Group 1, $n=20$ & Group 2, n = 27 & Group 3, n = 29 & Group of control, $n=16$ \\
\hline Average age (years), $M \pm m$ & $13.51 \pm 0.52$ & $14.08 \pm 0.41$ & $14.17 \pm 0.36$ & $14.41 \pm 0.47$ \\
\hline Number of boys, abs./ \% & $11 / 55.0$ & $14 / 51.8$ & $15 / 51.7$ & $9 / 56.2$ \\
\hline Number of girls, abs./ \% & $9 / 45.0$ & $13 / 48.2$ & $14 / 48.3$ & $7 / 43.8$ \\
\hline
\end{tabular}

To define functional abilities of muscular system static and dynamic endurance of skeletal muscles was estimated while fixing the maximal time period of given testing position sustaining in seconds (sec).

At the time of the endurance functional tests of skeletal muscles of all children with T1D included in the research, feeling "before" and "after" testing were assessed as satisfactory. Tests were performed 1 hour after eating to determine the concentration of glucose before, immediately after and 1 hour after end samples (in accordance with the recommendations of the Protocol of rendering medical aid to children with diabetes mellitus approved by Order № 254 of the MH of Ukraine dated 04/27/2006 with changes made in accordance with the Ministry of Health Orders № 55 (v0055282-09) dated 02/03/2009; № 864 (v0864282-13) dated 7/10/2013). The criteria for inclusion of patients into the research were: the consent of the patient and his parents for participation in the research; lack of ketoacidosis (ketone bodies of the urine were determined before and after the samples); the maximal level of glycemia on an empty stomach on the day of research did not exceed $10.5 \mathrm{mmol} / \mathrm{L}$, and the minimal level of glycemia was $5.7 \mathrm{mmol} / \mathrm{L}$. The average level of glycemia on an empty stomach in the first group was $7.34 \pm 0.48 \mathrm{mmol} / \mathrm{L}$, in the second group $-7.38 \pm 0.52$ $\mathrm{mmol} / \mathrm{L}$, in the third group $-7.84 \pm 0.48 \mathrm{mmol} / \mathrm{L}$. The research excluded patients with the lack of consent to participate in the research; children, with T1D with obesity and excess body weight; with the presence of acute inflammatory processes or congenital malformations in the stage of decompensation.

To define the endurance of neck flexor muscle groups all children were requested to hold the neck flexed when lying down on the back. The chest should be on the surface.

To define the static endurance of spinal extensors children were requested to lift the upper body and hold it above the surface while lying down on the abdomen with the head. the legs on the surface and hands crossed up behind

To define the muscular endurance of abs children were supposed to lift the legs upwards to the angle of $45^{\circ}$ and hold when lying on the back on the surface [10].

To define the endurance of the gluteus medius children were supposed to lift the leg up to the side up to the possible height and hold without the rotation when standing [11].

Total static muscle endurance (TSME) was also evaluated. The range of muscle quality was evaluated as a ratio of TSME to skeletal muscle index.

Skeletal muscle strength was estimated using the wrist spring dynamometer, which was squeezed by the patients' hand, in order to offset the age of a kid when estimating the muscle strength, one has applied the wrist strength index (WSI):

$$
\text { WSI }=(\text { wrist strength/body mass }(\mathrm{kg})) \times 100 \% \text { [2] }
$$

The test was carried out using the wrist rubber ringlike expander with the resistance equal to $20 \mathrm{~kg}$, one had to squeeze the expander during $30 \mathrm{sec}$.

All the results were analyzed using the set of statistic programs Statistica 13.0 (StatSoft Inc., № JPZ8041382130ARCN10-J). Parametrical methods that helped to evaluate simple average, mean squared deviation and standard error were applied for normally distributed rates. The method of correlation analysis was used to calculate the Pearson correlation coefficient in the normal distribution of features and the Spearman's rank correlation coefficient in their absence. The reliability of the differences in the results obtained for different groups in the normal distribution of characteristics was determined by the parametric (Student's criterion) method. Differences were considered to be significant at $P<0.05$ [12].

In planning this work the bioethical commission gave permission to conduct research. All patients signed informed consent to participate in the study. All procedures performed in studies involving human participants were in accordance with the ethical standards of the institutional and national research committee and within the $1964 \mathrm{Hel}-$ sinki declaration and its later amendments or comparable ethical standards. Informed consent was obtained from all individual participants included in the study. The full data set by children, their parents, and physician that support the findings of this study are not publicly available due to the ethics approval originally obtained.

\section{Results}

According to the results of research it was established that there was no significant difference in BMl in all examined groups and all the rates were considered to be in normal ranges (Table 2).

Instead, as the duration of T1D was increasing, a gradual decrease in skeletal muscle index in patients with diabetes mellitus was observed compared with controls, becoming statistically significant after 5 years of the disease $(P<0.05)$. Starting from the second year of the disease, there was a significant increase in the percentage of body fat $(P<0.05)$. Also, there is the increase in the dynamics of the disease ratio of "fat mass / muscle mass" $(P<0.05)$ compared with the indicator of both the control group and the $1^{\text {st }}$ group of patients with diabetes (Table 2). That is, an increase in the "length of time" of diabetes was accompanied by a component redistribution of body composition.

Taking into the account that changes in structural component of body may affect the functional muscle condition the next step of our investigation included static and dynamic test to estimate the muscle endurance. According to the data obtained after carrying out static endurance tests for examined muscle groups it was established that there was a deterioration of ability to hold the test position 
Table 2. The rates of BMI and fatty and muscle mass in children with T1D according the duration of disease, $\mathrm{M} \pm \mathrm{m}$

\begin{tabular}{|c|c|c|c|c|}
\hline Criteria, units & Group $1, n=20$ & Group 2, n = 27 & Group 3, n = 29 & Group of control, $n=16$ \\
\hline Body mass index, $\mathrm{kg} / \mathrm{m}^{2}$ & $18.99 \pm 0.7$ & $20,78 \pm 0,7$ & $20.36 \pm 0.57$ & $20.51 \pm 0.89$ \\
\hline Percent of fat in organism, \% & $16.86 \pm 0.91$ & $19.09 \pm 0.99 \S$ & $20.02 \pm 0.86^{\S \#}$ & $16.14 \pm 0.98$ \\
\hline Skeletal muscle index, \% & $81.39 \pm 1.08$ & $78.56 \pm 1.14$ & $77.33 \pm 1.10$ §\# & $81.10 \pm 1.17$ \\
\hline Fatty mass/muscle mass, $\mathrm{CU}^{*}$ & $0.21 \pm 0.01$ & $0.25 \pm 0.01 \S \#$ & $0.26 \pm 0.02^{\S} \#$ & $0.20 \pm 0.02$ \\
\hline
\end{tabular}

s: $\mathrm{P}<0.05$ in the period with the highest indicator of the control group; \#: $\mathrm{P}<0.05$ in the period with the highest indicator of group 1 ; *CU: conventional units.

Table 3. The rates of static muscular endurance in children with T1D counting the duration of disease, $M \pm m$

\begin{tabular}{|c|c|c|c|c|}
\hline Group of muscles examined, units & Group 1, $n=20$ & Group 2, n = 27 & Group 3, n = 29 & Group of control, $n=16$ \\
\hline Neck flexors, sec. & $53.57 \pm 5.17 \S$ & $42.75 \pm 2.91^{\S}$ & $35.84 \pm 2.66^{\S \#}$ & $90.82 \pm 9.47$ \\
\hline Muscles of abs, sec. & $18.67 \pm 2.2^{\S}$ & $21.12 \pm 1.87^{\S}$ & $18.22 \pm 1.52^{\S}$ & $52.83 \pm 6.06$ \\
\hline Spinal extensors, sec. & $21.18 \pm 1.87 \S$ & $20.54 \pm 1.76^{\S}$ & $18.33 \pm 1.16^{\S}$ & $38.25 \pm 3.78$ \\
\hline Left gluteus medius, sec. & $29.47 \pm 2.99 \S$ & $29.46 \pm 2.73^{\S}$ & $29.67 \pm 2.59 \S$ & $40.46 \pm 4.3$ \\
\hline Right gluteus medius, sec. & $30.59 \pm 3.45^{\S}$ & $30.36 \pm 2.21 \S$ & $31.46 \pm 2.77 \S$ & $43.23 \pm 4.7$ \\
\hline Total static muscle endurance, sec. & $157.21 \pm 11.47$ & $138.13 \pm 6.52$ & $127.12 \pm 8.13^{\S} \#$ & $259.09 \pm 18.18$ \\
\hline Rate of muscular quality, CU* & $2.00 \pm 0.15^{\S}$ & $1.88 \pm 0.10^{\S}$ & $1.59 \pm 0.11^{\S} \#$ & $3.26 \pm 0.28$ \\
\hline
\end{tabular}

§: $\mathrm{P}<0.05$ in the period with the highest indicator of the control group; \#: $\mathrm{P}<0.05$ in the period with the highest indicator of 1 group; CU*: conventional units.

Table 4. The rates of dynamic endurance of wrist and arm muscles in children with type 1 diabetes according to the duration of the disease, $\mathrm{M} \pm \mathrm{m}$

\begin{tabular}{|c|c|c|c|c|c|}
\hline \multicolumn{2}{|c|}{ Indicators, units } & Group 1, $n=20$ & Group 2, n = 27 & Group 3, n = 29 & Group of control, $n=16$ \\
\hline \multirow[t]{2}{*}{ WSI left, CU } & initial & $38.11 \pm 3.24 \S$ & $37.21 \pm 1.28^{\S}$ & $36.51 \pm 1.76^{\S}$ & $50.75 \pm 2.12$ \\
\hline & After test & $32.85 \pm 3.32^{\S}$ & $32.46 \pm 1.78^{\S}$ & $30.61 \pm 1.60^{\S}$ & $47.21 \pm 2.82$ \\
\hline \multicolumn{2}{|c|}{ WSI1/WSI2, left, CU } & $1.14 \pm 0.02$ & $1.16 \pm 0.03$ & $1.22 \pm 0.03^{\S \#}$ & $1.08 \pm 0.03$ \\
\hline \multirow[t]{2}{*}{ WSI right, $\mathrm{CU}$} & initial & $42.44 \pm 3.22^{\S}$ & $39.73 \pm 2.01^{\S}$ & $38.75 \pm 2.02^{\S}$ & $55.15 \pm 2.71$ \\
\hline & After test & $36.79 \pm 3,25^{\S}$ & $34.38 \pm 1.75^{\S}$ & $32.63 \pm 1.90^{\S}$ & $51.52 \pm 3.05$ \\
\hline \multicolumn{2}{|c|}{ WSI1/WSI2, right, CU } & $1.12 \pm 0.02^{\S}$ & $1.17 \pm 0.04 \S$ & $1.20 \pm 0.03^{\S}$ & $1.07 \pm 0.01$ \\
\hline
\end{tabular}

s: $\mathrm{P}<0.05$ in the period with the highest indicator of the control group; \#: $\mathrm{P}<0.05$ in the period with the highest indicator of $1 \mathrm{group}$; CU: conventional units.

in children with T1D regardless of duration of disease, which led to statistically significant decrease of total static muscular endurance compared to results obtained from testing the group of control (Table 3).

The worst rates of muscle endurance were observed in abdominal muscles. It was 2.5-2.9 times lower compared to rates of the control group. It should be pointed out that, as the duration of disease increased the rates of total static muscle endurance were getting worse through the neck muscles. If in the first year of the disease the endurance of this muscle group was reduced by 1.7 times compared with the indicators of the control group, then with a long course of diabetes (group 3) this indicator not only statistically differed from the values of the control group $(P<0.05)$, but was 1.5 times less than the same indicator in group $1(\mathrm{P}<0.05)$.

It was noticed that there was also worsening of muscle quality rates coming with changes in static muscle endurance in patients with T1D. There was a progressive decreasing of given indicator from $2.00 \pm 0.15 \mathrm{CU}$ in the first year of disease down to $1.59 \pm 0.11 \mathrm{CU}$ in patients from the $3^{\text {rd }}$ group, which was 2 times less than the same indicator obtained in the group of control.

The level of glycated hemoglobin ( $\mathrm{HbAc} 1)$ in the research group increased with increase of duration of T1D and amounted to first group $8.9 \pm 0.6 \%$, in the second group $-9.12 \pm 0.38 \%$, in the third group $10.31 \pm 0.28 \%$, It was established, that the reduced static muscle endurance in patients with $T 1 D$ is related to the increased level of $\mathrm{HbA} 1 \mathrm{c}(r=-0.35, \mathrm{P}<0.05)$. This correlation became the most significant during the first 5 years of disease $(r=-0.50, P<0.05)$. That means that the lack of diabetes control causes significant changes in glycemia and causes the development of chronic complications of diabetes mellitus, as well as impaired function of skeletal muscles.

When examining the dynamic endurance of wrist and arm muscles using the rates of BMI it was indicated that there was a decreased initial rate compared to the control group, as well as its even bigger decreasing after physical exertion (Table 4).

While WSI in the group of control decreased on average by $6.8 \%$ after physical exertion, patients with T1D had $13 \%$ less WSI index in the first 5 years of disease increasing up to $16 \%$ in patients of the $3^{\text {rd }}$ group $(P<0.05)$, which spoke about worsening of functional state of skeletal muscles and increased muscle fatigue, which was observed during the first years of disease and was in progress in terms of growing endurance. Additionally, the determined particularities of functional state of wrist and arm muscles were related to total muscular static endurance $(r=+0.43$ and $r=+0.37$, respectively for the left and right upper limbs, $P<0.05)$ and to the muscle quality rate $(r=+0.52$ and $r=+0.47$, respectively, $P<0.05)$.

\section{Discussion}

The results obtained show the children with T1D to have an obvious decrease of muscular endurance starting from the first year of disease. It is mostly affected by insufficient glycemic control which is proved by received correlation relationship between glycated hemoglobin 
and total static muscular endurance $(r=-0.35, P<0.05)$. At the same time, statistically significant decreasing of muscle mass occurs only after the $5^{\text {th }}$ year of the disease. Thus, disturbances in functional abilities of muscles on the background of chronic hyperglycemia already fixed during the first years of disease eventually lead to decrease of muscle mass, in other words to the development of diabetic myopathy. Moreover, in children with T1D an increase in the ratio between fat and muscle tissue in condition of normal body mass index was observed. One of the reasons causing increasing of fatty tissue percentage in patients with T1D is insufficient glycemic control ending up with chronic hyperglycemia. Wherein, excessed amount of glucose turns into a fat, because the fatty tissue is characterized by quite significant metabolic activity and is highly irresistible to insulin. The increasing percentage of fatty tissue leads to further metabolic response dysfunction to exogenous insulin, that is to say towards insulin resistance [13]. The receptors of insulin situated in muscles play the main role in glucose regulation, while muscle tissue itself is the main place of glucose utilization, because the glucose is considered to be the source energy material necessary for their functioning [14]. Monaco C. M. in his research supposed, that repeated insulin injections may cause periods of relapses intracellular hyperglycemia in myofibrils. Thus, patients with T1D have a greater dependence on glycolytic metabolism due to lack of mitochondrial function and accompanying changes in muscle structure [3]. At the same time, we taking into account, that insulin is considered to be a catabolic hormone promoting the synthesis of protein by facilitating the muscle proteins production. The defects of its signals transmitting leads to lack of protein production and excessed protein degradation, which eventually causes the muscle power and muscle mass deficiency [15].

\section{Conclusions}

1. Functional condition of skeletal muscles in children with type 1 diabetes is characterized by deficiency of static and dynamic muscular endurance.

2. The first signs of violation of functional condition of skeletal muscles are observed over the first year of disease and progress as the duration of a disease increases and eventually leads to decrease of muscular mass and diabetic myopathy developing.

3. The major factor of risk contributing the worsening of functional condition of muscles is insufficient glycemic control.

Prospects for further studies. We plan to determine the predictors formation of diabetic myopathy in children with T1D.

\section{Funding}

The performed study is a fragment of the scientific and research work of Zaporizhzhia State Medical University on the topic: "Prediction of the occurrence, diagnosis and treatment of disorders of the musculoskeletal system in children with diabetes" (state registration 0119U100456).

Conflicts of interest: authors have no conflict of interest to declare. Конфлікт інтересів: віАсутній.
Надійшла Ао редакції / Received: 04.05.2020

Після Аоопрацювання / Revised:26.05.2020

Прийнято Ао Аруку / Accepted: 09.06.2020

Information about authors:

Pashkova O. Ye., MD, PhD, DSc, Professor of the Department of Hospital Pediatrics, Zaporizhzhia State Medical University, Ukraine.

ORCID ID: 0000-0002-3935-5103

Chudova N. I., MD, Assistant of the Department of Hospital Pediatrics, Zaporizhzhia State Medical University, Ukraine. ORCID ID: 0000-0001-5641-1843

\section{Відомості про авторів:}

Пашкова 0. Є., А-р меА. наук, Аоцент, професор

каф. госпітальної пеАіатрії, Запорізький Аержавний медичний університет, Україна.

Чудова Н. І., асистент каф. госпітальної педіатрії, Запорізький Аержавний медичний університет, Україна.

\section{Сведения об авторах:}

Пашкова Е. Е., А-р меА. наук, Аоцент, профессор каф. госпитальной педиатрии, Запорожский госуАарственный медицинский университет, Украина.

Чудова Н. И., ассистент каф. госпитальной педиатрии,

Запорожский государственный меАицинский университет, Украина.

\section{References}

[1] Maratova, K., Soucek, O., Matyskova, Ja. Hlavka, Zd., Petruzelkova, L., Obermannova, B Pruhova, St., Kolouskova, S., Sumnik, Zd. (2018). Muscle functions and bone strength are impaired in adolescents with type 1 diabetes. Bone, 106, 22-27. http://doi.org/10.1016/j. bone.2017.10.005

[2] Dydyshko, Yu. V., \& Shepel'kevich, A. P. (2015). Vozmozhnosti otsenk sostoyaniya myshechnogo komponenta $v$ norme i pri sakharnom diabete 1-go tipa [Opportunities for assessing the state of the muscle component in normal conditions and in type 1 diabetes mellitus]. Meditsinskaya panorama, (5), 45-50. [in Russian].

[3] Monaco, C. M. F., Perry, C. G. R., \& Hawke, T. J. (2017). Diabetic Myopathy: current molecular understanding of this novel neuromuscular disorder. Current Opinion in Neurology, 30(5), 545-552. https://doi. org/10.1097/wco.0000000000000479

[4] Hirata, Y., Nomura, K., Senga, Y., Okada, Y., Kobayashi, K., Okamoto, S., Minokoshi, Y., Imamura, M., Takeda, S., Hosooka, T., \& Ogawa, W. (2019). Hyperglycemia induces skeletal muscle atrophy via a WWP1/KLF15 axis. Jci Insight, 4(4), Article e124952. https://doi. org/10.1172/jci.insight.124952

[5] Nakamura, P. M., Mielke, G. I., Horta, B. L., Assungdo, M. C., Goncalves, H., Menezes, A. M. B., Barros, F. C., Ekelund, U., Brage, S. Wehrmeister, F. C., Oliveira, I. O., \& Hallal, P. C. (2017). Physical Activity Throughout Adolescence and Hba1c in Early Adulthood: Birth Cohort Study. Journal of Physical Activity \& Health, 14(5), 375-381. https://doi. org/10.1123/ipah.2016-0245

[6] Peters, A. M., Snelling, H. L. R., Glass, D. M., \& Bird, N. J. (2011). Estimation of lean body mass in children. British Journal of Anaesthesia, 106(5), 719-723. https://doi.org/10.1093/bja/aer057

[7] Zanardo, M., Doniselli, F. M., Esseridou, A., Tritella, S., Mattiuz, C. Menicagli, L., Di Leo, G., \& Sardanelli, F. (2018). Abdominal CT: a radiologist-driven adjustment of the dose of iodinated contrast agent approaches a calculation per lean body weight. European radiology experimental, 2(1), 41. https://doi.org/10.1186/s41747-018-0074-1

[8] Kim, H. T., Kim, H. J., Ahn, H. Y., \& Hong, Y. H. (2016). An analysis of age-related loss of skeletal muscle mass and its significance on osteoarthritis in a Korean population. Korean Journal of Internal Medicine, 31(3), 585-593. https://doi.org/10.3904/kiim.2015.156

[9] Kupusinac, A., Stokic, E., \& Doroslovacki, R. (2014). Predicting body fat percentage based on gender, age and BMI by using artificial neural networks. Computer Methods and Programs in Biomedicine, 113(2), 610-619. https://doi.org/10.1016/i.cmpb.2013.10.013

[10] Proskurov, E. M. (2012). Funktsional'noe sostoyanie serdechno sosudistoi sistemy u mal'chikov 10-11 let posle staticheskikh uprazhnenii s sobstvennoi massoi tela [The functional state of cardiovascular system for boys 10 - 11 years old after static exercises with deadweight of body]. Pedagogika, psihologia ta mediko-biologicni problemi fizicnogo vihovanna i sportu, (11), 79-84. [in Russian]. https://doi.org/10.6084/ m9.figshare.97367.v1 
[11] Vasil'eva, A. A., \& Konovalova, T. G. (2019). Otsenka silovoi vynoslivosti myshts spiny i pressa kak sposob kontrolya profilaktiki skolioza studentov 3 kursa 2-oi funktsional'noi gruppy [Evaluation of strength endurance of the muscles of the back and the press as a way to control the prevention of scoliosis of 3rd year students of the 2nd functional group]. Studencheskii, (22). [in Russian]. https://sibac.info/journal/ student/42/122149.

[12] Truhacheva, N. V. (2017). Meditsinskaya statistika: uchebnoye posobiye [Medical statistics: training manual]. Rostov na Donu: Feniks. [in Russian].

[13] Abdulkadirova, F. R., Ametov, A. S., Doskina, E. V., \& Pokrovskaya, R. A. (2014). Rol' lipotoksichnosti v patogeneze sakharnogo diabeta 2 tipa i ozhirenii [The role of lipotoxicity in the pathogenesis of type 2 diabetes and obesity]. Ozhirenie i metabolizm, 11(2), 8-12. [in Russian]. https://doi.org/10.14341/omet201428-12

[14] Carnagarin, R., Dharmarajan, A. M., \& Dass, C. R. (2015). Molecular aspects of glucose homeostasis in skeletal muscle-A focus on the molecular mechanisms of insulin resistance. Molecular and Cellular Endocrinology, 417(C), 52-62. https://doi.org/10.1016/j.mce.2015.09.004

[15] Umegaki, H. (2015). Sarcopenia and diabetes: Hyperglycemia is a risk factor for age-associated muscle mass and functional reduction. Journal of Diabetes Investigation, 6(6), 623-624. https://doi.org/10.1111/ jdi. 12365 